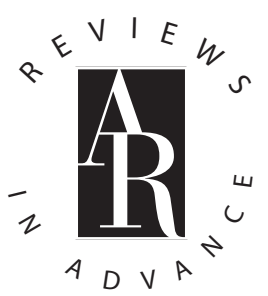

\title{
Societal Responses to Terrorist Attacks
}

\author{
Seymour Spilerman ${ }^{1}$ and Guy Stecklov ${ }^{2}$ \\ ${ }^{1}$ Department of Sociology, Columbia University, New York, New York 10027; \\ email: spilerman@columbia.edu \\ ${ }^{2}$ Department of Sociology and Anthropology, Hebrew University, Jerusalem 91905, \\ Israel; email: stecklov@huji.ac.il
}

Annu. Rev. Sociol. 2009.35:167-89

The Annual Review of Sociology is online at soc.annualreviews.org

This article's doi:

10.1146/annurev-soc-070308-120001

Copyright (c) 2009 by Annual Reviews. All rights reserved

0360-0572/09/0811-0167\$20.00

\section{Key Words}

Israel, Northern Ireland, terrorism, coping, resilience, economy

\begin{abstract}
Terrorist attacks in the United States and in Western Europe have been rare, and public awareness of the terrorist menace has largely been molded by a few horrific events. In contrast, other countries have experienced chronic terrorism, with attacks on buses, restaurants, coffee shops, and retail establishments. In this review, we assess the impact of terrorism on civilian society in the United States, Northern Ireland, and Israel. We examine the psychological effects, the adaptations made by individuals to enhance their safety, and the consequent adjustments made by institutional actors and by commercial establishments to ensure continued economic viability. We review the various theories of societal adjustments to exogenous shocks and point out that a very different formulation is required for the case of chronic terrorism than for the societal experience of a one-time attack.
\end{abstract}




\section{INTRODUCTION}

Terrorism has become a prominent topic of public discourse in the twenty-first century. While hardly unknown in previous eras (e.g., the Baider-Minehoff gang, the Weathermen, and the much earlier Narodnaya Volya), with few exceptions terrorism was not a factor in the everyday life of residents of Western countries until recently. Reflecting the low salience of this phenomenon prior to the attacks of September 11, 2001, in the United States - and possibly because of what Joas (2003) has decried as a utopian bias in examining society without its wars and conflicts-social science research gave only passing consideration to terrorism in discussions of collective behavior.

The 9/11 attacks and the similar assaults in Great Britain and Spain changed the terrain and have stimulated an immense amount of writing and research on terrorism. Most of this work has focused on the perpetrators, with the goal of illuminating the characteristics of terrorist groups - their motives, organizational structure, recruitment strategies, tactics, and support bases (e.g., Hoffman 2006, Victoroff 2005, Turk 2004). Much attention has been given to issues of definition: ${ }^{1}$ how to distinguish terrorism from related phenomena such as guerrilla warfare, lynching, and political assassination (National Research Council 2002; Tilly 2004; Smelser 2007, pp. 229-46). In the process, researchers have noted that terror is used by a range of actors not usually thought of as terrorists-e.g., the Mafia threatens and intimidates to enforce compliance with extortion demands; Great Britain obliterated Dresden with

${ }^{1}$ While matters of definition are relevant to investigations of most social phenomena, they are rarely accorded much space in research reports. However, this is not the case with studies of terrorism, in part because of the political implications of this designation (e.g., terrorists versus freedom fighters). Thus, the brief report by the National Research Council (2002) gives five pages to issues of definition; Hoffman (2006) devotes a chapter and Smelser (2007) an appendix to definitional problems. A fairly consensual formulation is that terrorism is politically motivated violence, carried out by individuals and nonstate organizations with the intent of influencing an audience beyond the immediate victims (Shughart 2006). the intent of demoralizing the civilian population of Germany (National Research Council 2002, p. 15).

The literature on terrorists and terrorist organizations is now quite voluminous and permits some previously held notions to be discarded. Thus, based on interviews with captured terrorists, there is little evidence of psychopathology or of personality disorder as factors in their behavior (Atran 2003, Sagerman 2004). Also, terrorists do not come from the economically deprived segments of a society (Atran 2003, Krueger \& Maleckova 2003); rather, their commitment appears to stem from prosocial attitudes - a deep identification with the values and aspirations of their community (Krueger 2007, chapter 1; Turk 2004; also Haddad 2004 on social support for terrorists). In this sense, the self-sacrifice of a suicide bomber is reminiscent of Durkheim's altruistic suicide category.

With respect to organizations that use terror, Ricolfi (2005) and Victoroff (2005) see terror attacks as part of the repertoire of strategies a militant group might employ in pursuing its objectives, whether to cast off oppression, attain a religious goal, or cleanse a country from an unwanted ethnic population. Acts of terror bring deeply felt grievances to the attention of an otherwise indifferent public. They raise the cost of defending the status quo, and the desire for a cessation of the attacks provides the terrorist group with a bargaining chip in negotiations (Hoffman 2006, chapter 8; Gambetta 2005 , chapter 8 ). There are special advantages from suicide attacks: They do not require sophisticated equipment; they are the ultimate "smart bomb"; when successful there is no assailant to interrogate; and they convey to the public the depth of commitment to the cause.

If we are beginning to develop a coherent understanding of terrorist groups and the characteristics of their members, we are less far along in our comprehension of the adjustments made by residents and by organizational actors in an impacted country. Yet such considerations tap issues of both the effectiveness of terrorism as a strategy and notions of societal 
resiliency: how the cascading effects of the disruptions are managed, the types of adaptations made by individuals and families, the costs to different sectors of the economy, and the formulation of government policies intended to maintain normalcy in a menacing environment. It is this array of issues, concerning the scope and breadth of a society's response to terrorist attacks, that are the concerns of the present article.

Conceptualization and theory development with respect to societal adjustments are very much a function of the attack history in a country. In this regard, it is useful to distinguish between two quite different kinds of experiences with terrorism - the case of a single event (or small number of attacks), massive in scale and directed at critical infrastructure sites or targets of symbolic significance, and the case of repeated attacks over many years in which the targets can be quite varied.

The first sort of experience, exemplified by the $9 / 11$ attack in the United States and by more recent bombings in Great Britain and Spain, has given rise to a literature that emphasizes prevention and preparedness for a future assault of similar, catastrophic proportions. The focus in this literature is on the form a next attack might take (whether nuclear, chemical, or biological), on countermeasures for interdicting an attempt, and on strategies for mitigating the impact of a successful attack - training first responders, ensuring interoperability of communications equipment, stockpiling medical supplies, and the like. This type of experience has also produced a rich literature on the psychological reactions to an attack.

The second type of exposure to terrorism has generated a literature that augments the aforementioned issues with analyses of the behavioral responses to an ongoing terrorist threat. Here, the presumption is that the experience of repeated attacks has encouraged individuals to modify their routine activities in order to minimize future risk, and this has perturbed the social system from its prior equilibrium. A search then ensues for new social arrangements that are compatible with personal safety; this, in turn, requires adaptations on the part of commercial establishments and by other organizational actors seeking to maintain their viability. Examples of countries and regions that have had this sort of experience with terrorism are Israel, Sri Lanka, Northern Ireland, and northern India.

We discuss the literatures relevant to both histories of exposure in this review. However, because our main interest concerns issues of societal resiliency and organizational adaptation in the face of a terrorist threat, the second is of greater relevance. In the context of repeated attacks, the adjustments tend to be long lasting and more deeply assimilated into the fabric of the society than in cases of a single attack, however massive in scale. Also, because there is a considerable research literature on the impact of terrorism in Israel, we draw much of our material from that country, although we supplement the Israeli experience with studies in other countries, especially the United States and Northern Ireland.

\section{A SINGULAR MASSIVE ATTACK}

Three targets were struck on September 11, 2001 - the World Trade Center, the Pentagon, and a commercial airplane on its way to Washington, DC. In the mind of the public and in the research literature, however, this date is most deeply associated with the destruction of the World Trade Center. In the studies that have examined the consequences of the 9/11 attack, two themes are emphasized: the mental health effects on the population and methods to enhance the preparedness of the country, given the possibility of a future terrorist attack.

The social science community has participated in this endeavor. As part of the undertaking, there has been a search for theoretical frameworks that would permit an efficient assessment of the consequences of a terrorist attack. From an applied perspective, the importance of theory would be to forecast the likely effects of an attack on population morale and societal functioning-how the impact differs by type of attack, choice of target, and 
characteristics of the impacted population, and, further, how the ensuing disruptions are absorbed and managed.

To the extent that an inductive approach is taken to theory construction, which is characteristic of the work in this area, the U.S. experience of a very few terrorist attacks is a liability. The number of observations can be increased by adding to the list the Oklahoma City bombing in 1995 and the anthrax mailings of 2001, as well as the large-scale attacks in Tokyo, London, and Madrid. However, no literature has compared these attack sites in terms of the impact on community and on institutional arrangements, aside from some studies of mental health effects (e.g., Valverde 2005, Vazquez et al. 2006). Rather, the approach taken to theory development at the level of organization and community effects has largely been one of extrapolating from the literature on disasters, a research area that received much attention in the 1950s and 1960s (Barton 1963, 1969; Baker \& Chapman 1962; Quarantelli \& Dynes 1977) and has benefited from a resurgence of interest following Hurricane Katrina (Pais \& Elliot 2008, Tierney 2007).

The disasters literature is certainly relevant-a successful terror attack is a traumatic event for the affected community, and there are similarities in the response, whether the cause is natural or the workings of a malevolent actor. It is also the case that enough communities have been stricken by natural and industrial disasters that one can theorize about organizational and community reactions. Thus, the National Research Council (2002) resorted to the disaster paradigm in its discussion of community responses to terrorist strikes; similarly, Smelser (2007, chapter 5) and Fullerton et al. (2003) utilize this framework in their consideration of the impact of terrorist attacks.

The imagery that is central to the disaster paradigm is one of an impulse shock to the social system, which is then associated with a succession of stages in the community's response. As summarized by the National Research Council (2002, pp. 40-41), the stages are (a) initial disbelief and denial, $(b)$ a rush to the scene of the disaster, $(c)$ the development of solidarity in the affected community, $(d)$ subsequent scapegoating and blame of individuals believed to have been remiss in preparation or response, and (e) a gradual return to routine activities. The Council's report adds the assessment that each of these stages was present in the aftermath of the $9 / 11$ terrorist attacks.

The disasters literature is nuanced in its coverage of both community and individual responses. One theme that has received much attention concerns role behavior and role conflict, with clear findings that family responsibilities intrude into the performance of organizational roles. Thus, first responders who are unsure of the safety of family members are more likely to abandon work than are responders without family in the impacted area. At the same time, shock and panic reactions are less common among persons who have family responsibilities. Other findings include a heightening of community solidarity and a reduction in crime following a disaster, a recognition of the importance of clear lines of organizational jurisdiction, and the status of the public as a source of volunteers and supplies but also an obstacle to efficient recovery operations (Killian 1952, Form \& Nosnow 1958, Barton 1962, Hill \& Hanson 1962, Tierney 2007).

These themes are echoed in the writings on 9/11. However, an essential difference between a natural disaster and a terrorist attack is the presence in the latter of a designing actor who is intent on inflicting pain and suffering. This is a distinction of consequence because just as a nation learns from an attack about ways to increase its vigilance, the agile terrorist can adapt by changing the location and method of attack (Fullerton et al. 2003, p. 4). This makes it difficult for a threatened community to protect itself, and the disruption in feelings of security is a potent generator of stress (Baum \& Dougall 2002). Indeed, the psychological impact of terror may have less to do with destructive power than with its ability to evoke fear and anxiety. Thus, in assessing the effects of different types of traumatic events, Fullerton et al. (2003, p. 6) have ranked terrorism as one of "the most 
powerful and pervasive generators of psychiatric illness, distress, and disrupted community and social functioning."

The disaster model is especially problematic for the case of multiple attacks over a long time period-what we term "chronic terrorism." Here, issues of psychiatric illness and effects on population morale cannot be tied to the onset of a particular strike, and the ensuing organizational adjustments tend to be long lasting and permeate deeply into the societal fabric. In short, the impulse model of system disruption lacks verisimilitude in mimicking the adaptation to this experience with terrorism. While the imagery in disaster studies pertains to rare events, the experiences of Israel and Northern Ireland make the threat of attack an ongoing risk (Tierney 2007).

\section{Psychological Effects}

What, then, has been learned about the consequences of the World Trade Center attack? Since the problem of small $N$ can be avoided in studies using individual-level data, there is a robust literature on the mental health effects of this assault, indexed by symptoms of fear, anxiety, and depression. Thus, in a national survey of stress reactions in the week following the attack, Schuster et al. (2001) found that $44 \%$ of adults reported substantial symptoms. The magnitude of the effect differed by social characteristics. Women reported greater stress than did men; distance from the World Trade Center was negatively associated with stress; and hours of television viewing of the attack showed a positive correlation, though this last finding raises concerns of causal direction and endogeneity. Respondents coped with the stress by talking about the attack, turning to religion, and making donations.

Some two months after the World Trade Center attack, Galea et al. (2002) surveyed symptoms of post-traumatic stress disorder (PTSD) and depression in Manhattan and found elevated levels. Even within this borough, there was a strong effect of distance from the site $(20.0 \%$ of lower Manhattan residents reported PTSD symptoms versus $6.8 \%$ in upper Manhattan); also, individuals who witnessed the towers collapse reported elevated stress, as did persons involved in the rescue effort. Similar to the earlier survey, women reported more severe symptoms than did men. A further analysis of the data (Vlahov et al. 2002) showed that the psychological distress was expressed behaviorally with increased consumption of cigarettes, alcohol, and marijuana.

Jones et al. (2006) describe the differential effects of the attacks on civilians and emergency service personnel in New York, noting the very high rate of stress-related maladies among fire department rescue workers. The illnesses did not occur immediately, and the authors speculate that they were exacerbated by repeated exposure to the impact site and by the cumulation of funerals that were attended by the firefighters. Delayed onset of stress disorders have also been reported by Holman et al. (2008). In a three-year follow-up of a national sample that had completed a health survey prior to $9 / 11$, Holman and colleagues examined the extent to which stress reactions predicted later cardiovascular outcomes. Adjusting for exogenous risk factors (pre-9/11 cardiovascular and mental health symptoms) and degree of exposure to the attack (hours watched of TV coverage), they concluded that symptoms of acute stress shortly after the attack were responsible for a $53 \%$ increase in cardiovascular ailments.

The results reported by Schuster et al. (2001) concerning the association of distress feelings with physical and psychological proximity to the attack (the latter indexed by amount of television viewing) appear to be robust in that Schlenger et al. (2002), using a different national sample, noted similar effects for the distance variables. Indeed, viewing the World Trade Center attack on television had much the same stress impact as physical proximity. For this reason, it is not surprising that there is evidence of strong emotional and behavioral reactions to the $9 / 11$ strike from as far away as Great Britain (Salib 2003).

Studies of terror attacks in other countries have produced findings that are largely 
consistent with the World Trade Center event. Vazquez et al. (2006), analyzing stress reactions in Madrid in the week following the March 11, 2004, attack in that city, found elevated PTSD levels. Again, the stress was higher among women, among residents who lived near the attack site, and among TV viewers of the event, though the last effect was small. An assessment of reactions to the London bombing of July 7, 2005 (Rubin et al. 2005), showed a similar result for gender, although physical proximity had no effect. Additionally, Muslims in Great Britain evidenced greater distress than persons of other faiths, and individuals who were uncertain about the fate of family members showed elevated stress; neither result is remarkable. What is noteworthy, and is discussed below, are findings of higher distress levels in persons who had no prior experience with terrorism (34\% versus $23 \%$ ), and of intentions to change mode of transportation in light of the attack-less use of trains and buses (32\%) and greater reliance on autos.

Rubin et al. (2005) claim that the traumatic impact of the London attack was less severe than the psychological effects of the strike on the World Trade Center. They attribute the difference to the greater loss of life in the United States but also speculate about the inuring effect of exposure to terrorism over a long period, such as had been the experience of Londoners from the IRA bombings. Interestingly, a similar assessment, referencing Basque terrorism, was proposed by Lopez-Rousseau (2005) to explain why Spaniards exhibited a relatively mild reaction to the March 11 bombing in Madrid, though his conclusion is based on changes in transportation usage, not trauma symptoms.

The theme of acclimation to chronic terror is developed in the next section with respect to Israel and Northern Ireland; both countries have had to cope with multiple attacks. What we note here is that the challenge of terrorism to personal security has a very different trajectory in the case of a single attack. In particular, Baum \& Dougall (2002) point to the role of "low points" in the experience of a traumatic event - the moment when an impacted population concludes that the worst is over and that matters will now improve. Disasters and singular terrorist attacks have low points, but cases of repeated terror lack an evident transition-the all clear signal might never come-suggesting that high levels of stress and anxiety could become a permanent fixture in such countries. At the same time, others (e.g., Lopez-Rousseau 2005, Rubin et al. 2005) have written of the inuring effects of repeated assaults, which would operate to moderate the stress reaction to a new attack.

\section{Social and Organizational Responses to a Single Attack}

The literature about $9 / 11$ suggests that the effects on the U.S. economy were modest. For several days after the strike the stock markets were closed and there was a steep sell-off when they reopened (the DOW index declined by $14 \%$ ), but in subsequent weeks the recovery was rapid. Insurance companies, airlines, and the tourist sector showed a longer period of recession (Lenain et al. 2002, Jackson 2008). There also were a variety of short-term dislocations in New York City: an oversupply of rental space in tall buildings, declines in employment and earnings, and a reduction in hotel occupancy (Chernick 2005). However, the overall assessment by Chernick is one of resilience and a rapid return to normality following the attack. Bruck \& Wickstrom (2004), summarizing the findings from a symposium on economic consequences of terror, largely concur with this appraisal. In contrast, Frey et al. (2007) suggest that terrorism leads to a lessening in life satisfaction (formulated as the monetary value of a reduction in the risk of harm). However, the modest behavioral changes made so far by Americans do not support this pessimistic contention.

In the main, this literature has focused on issues of prevention and preparation. It is replete with discussions of detection methods for the various noxious materials a terrorist might employ, of strategies for reducing the 
vulnerability of potential targets, and of approaches to organizing first responders (e.g., Kirschenbaum 2006, Grosskopf 2006, Howitt \& Pangi 2003); much of this work was funded by the Department of Homeland Security. The influence of the disaster-response model is evident in these writings. In comparison, while countries that have experienced repeated terror attacks certainly have the same concerns, those literatures are more attuned to adjustments made by individuals in order to minimize their risk-namely, the dynamics of the adaptations, differences by population groups, and implications of the behavioral changes for institutional actors and for the various sectors of the economy.

\section{CHRONIC TERRORISM: PSYCHOLOGICAL EFFECTS}

Northern Ireland and Israel have each been the site of repeated terrorist attacks over many years. In regard to Northern Ireland, Curran \& Miller (2001) report that between 1969 and 1999 there were 3740 deaths attributable to "the troubles," the term by which this conflict is known; civilians accounted for some 54\% of these casualties. Similarly, Israel has a long history of living with terrorism, dating to its founding in 1948. In the most recent wave of violence, the attacks have been carried out by Palestinians, crossing into Israel from Gaza and the occupied West Bank. During the period 2000-2005, there were 135 attacks with at least one fatality, accounting for 588 deaths (calculations from data of the International Institute for Counter Terrorism 2005).

While chronic terrorism has dominated daily life in each country, the structural underpinnings of the two conflicts bear few similarities, and quite different psychological and behavioral responses have been elicited. The violence in Northern Ireland is an outgrowth of communal strife between religious denominations that reside in neighborhoods adjacent to one another, scattered throughout the country. Each has an affiliated paramilitary organization that provides protection but that also undertakes bombings and shootings of civilians on the other side, either to exact retribution for a past attack or to cleanse a mixed neighborhood of unwanted residents. For our purposes, an essential feature is that the terrorist attacks have taken place in a context that is marked by diverse manifestations of sectarian conflict-marches, riots, and pitched battles between the paramilitary groups. While the bombings and shootings have the character of terrorist attacks, it is difficult to distinguish their effects on the population from those of the other expressions of the conflict.

Terrorism in Israel, by contrast, has occurred in the context of an asymmetric relationship between Israelis and Palestinians. Within the boundaries of the state there is ethnic and religious tension but no contending groups in armed conflict with one another; indeed, there is a considerable consensus (among Jewish Israelis) with regard to the goal of maintaining a democratic state with a Jewish patina. Rather, terrorism has emerged from the frustrations of Palestinian residents of Gaza and the West Bank who do not accept Israel as a legitimate state and who have limited opportunity to fulfill their own national aspirations. These frustrations are aggravated by the settlement policies of Israel in the West Bank, ${ }^{2}$ as well as by an unwillingness of leaders on both sides to negotiate a compromise.

In Israel, then, terrorism in recent years has taken the form of cross-border attacks from the Palestinian territories, often by suicide bombers. The targets have been restaurants, retail stores, buses, and other places where crowds gather. As a societal setting that has absorbed the attacks, aside from the fact of repeated assaults, the Israeli experience resembles more

\footnotetext{
${ }^{2}$ Although not addressed in this review, there have been terrorist attacks by Israeli settlers against Palestinians in the West Bank. These attacks are not considered here because our focus is on the societal response to terrorism, and there is little information on adaptations by the Palestinian population to the violence committed against them. A closely related issue, that of Palestinian life under the Israeli occupation of the West Bank, is discussed in Allen (2008) and Rosenfeld (2004).
} 
closely that of the United States than Northern Ireland, the latter with its contending communities locked in a dance of violence.

\section{Coping Style in Northern Ireland}

In the case of chronic terrorism, the literature has addressed somewhat different questions from those in a single attack. The key new ingredient is that of coping style, a recognition of the fact that the threat is omnipresent and that an individual is continually at risk in his or her daily activities. Coping style refers to how individuals manage the risk; it has both a social and a psychological dimension. At the social level, the literature examines rational adjustments by individuals, such as avoidance of high-risk settings, and the consequent adaptations by commercial actors seeking to maintain their viability. At the psychological level, coping style refers to an individual's cognitive processing of terror and trauma-essentially the way that these stressors are internalized and integrated into a person's psyche.

The linkage between trauma and psychological coping style is most strongly articulated in the writings on Northern Ireland. As Dorahy \& Paterson (2005) note, sectarian strife has been intricately woven into the fabric of the country, with shootings and bombings not an extraordinary occurrence during the past 30 years. Consequently, many of the symptoms of PTSD cited in Vazquez et al. (2006, p. 66) that are taken as indicators of emotional illness in the case of a single terrorist attack (e.g., hypervigilance, avoidance of places associated with the trauma) can, in fact, be functional for survival in the context of an ongoing existential threat. In essence, a new normality develops that fits the parameters of an abnormal social environment.

Analogous to studies of the World Trade Center attack, the literature on Northern Ireland includes routine examinations of posttraumatic stress reactions. However, the findings from this body of research are not consistent. Some have argued that the conflict has generated pervasive emotional trauma (e.g.,
Loughrey et al. 1988, Dorahy \& Paterson 2005), while other investigators find only modest effects on psychiatric morbidity (Curran 1988, Muldoon et al. 2000, Murphy \& Lloyd 2007).

In recognition of the unique conflictual terrain of Northern Ireland, the conceptual formulation of psychological effects has been broadened by a consideration of "dissociation" and "dissociative coping style" (Dorahy \& Paterson 2005, Dorahy et al. 2006). Dissociative coping refers to the emotional processing of trauma using defenses such as denial, avoidance, and distancing, in place of a more healthy integration of the totality of a horrific experience into the psychic self (Middleton 2004). It often takes the form of splitting reality into the good and bad, rather than accepting the grayness of most experiences. Dissociative coping has particular relevance to the conflict in Northern Ireland because it facilitates the projection of blame and hostility onto the opposing community, while heightening solidarity within one's own group.

An anomalous finding from the research on Northern Ireland is that dissociative coping can have a positive effect on mental health and on the processing of acute stress, despite the distortion of reality associated with this defense mechanism (Curran 1988, Curran \& Miller 2001). The splitting of reality provides a target for rage and anger, but it also provides a supportive community that can validate one's traumatic experience and help ward off feelings of grief and helplessness (Middleton 2004, Dorahy \& Paterson 2005). In general, dissociative coping appears to fit well with the sort of psychological adaptation that is functional in a conflict characterized by intense sectarian violence. At the same time, by heightening feelings of suspicion and reducing empathy for the other, this coping style deepens the division between the communities and makes reconciliation and resolution of the conflict that much more difficult (Muldoon et al. 2000, Campbell \& Healey 1999).

This is a painful literature to review because it makes clear the corrosive effects of intractable 
sectarian violence, especially in an ecological setting with intertwined neighborhoods, and the resulting psychological burden on the inhabitants of the country. Over time, the social consequences of the conflict have come to include heightened residential segregation and the abandonment of mixed neighborhoods, hesitancy in crossing boundary lines, and a consequent duplication of commercial activities, schools, and health-care facilities (Curran 1988, Campbell \& Healey 1999). Clearly, we are dealing here with much more than the effects of terrorist attacks; rather, this is a society that is deeply fractured, socially and politically. The combination of these two factors provides a fertile terrain for dissociative coping as a style of psychological adaptation.

It is of some interest to speculate about the different trajectories in the level of stress symptomology in Northern Ireland and in the United States. In the former, the possibility of terrorist violence became part of the normality, and people adopted a coping style that fit with this precarious existence. Indeed, young persons who grew up without ever knowing a safe environment exhibited low levels of distress during the troubles (Joseph et al. 1993, Murray \& Clifford 1988). Since the Belfast agreement of 1998, however, there has been an increase in stress symptoms, raising the possibility that the prior coping strategies might well be maladaptive for psychological well-being in a peaceful setting (McDonald 2007, Muldoon et al. 2000). In contrast, the one-time attack of September 11 was outside the range of normal experience for residents of the United States. It provoked much acute stress but did not alter one's concept of normality or require a modification of coping style. As a result, with the passage of time, the heightened stress level receded.

\section{Resiliency in Israel}

In studies of the Israeli experience, the formulation of psychological effects has taken a different direction. Although Israelis have had to confront chronic terrorism, their society is relatively cohesive, ${ }^{3}$ not riven by violent sectarian contention. In Israel, terrorism does not have the flavor of punishment or retribution, nor has it served the goal of clearing out mixed neighborhoods. Rather, the intent behind the attacks conforms with the traditional objectives of terrorist groups, namely to demoralize a population by highlighting the inability of the government to protect its citizenry, with the hope of using the threat of mayhem to secure favorable terms in negotiation. In this situation, the matter that is problematic for the society, and the theme that is emphasized in research studies on Israel, is that of resiliency in the face of repeated attacks. This theme appears in several guises: in studies of population morale, in examinations of coping styles and their consistency with sound mental health, as well as in broader formulations of the emotional well-being of the Israeli population.

Interestingly, research on the Israeli experience has made little use of the literature on Northern Ireland, though there are many references to the World Trade Center attack in the United States and to studies of acute stress spawned by that event. Using data collected a few days after a wave of terrorist assaults, Gidron et al. (2004) report higher levels of PTSD in women than in men, a finding that appears to be robust across countries, but a lessening of the symptoms to the extent that the government is perceived as being in control of the threat. Shalev et al. (2006) add the finding that proximity to an attack site- a strong correlate of stress symptoms in U.S. studies-had no impact on PTSD in Israel, with the interpretation that Israelis feel exposed and vulnerable irrespective of where they reside. Stecklov

\footnotetext{
${ }^{3}$ Arab citizens of Israel constitute some $20 \%$ of the population. Although they express solidarity with their Jewish counterparts, this cohesion is to some extent imposed on them by the Jewish majority. There has been some research on their reactions to terrorist attacks on Israel, and these studies are discussed in this review. With respect to Jewish citizens, there has been a decline in cohesion from a very high level in the initial years of the state. See Cohen (1988) for a temporal analysis of social cohesion in Israel (proxied by the emigration rate) in relation to external threats.
} 
\& Goldstein (2004) have linked the stress literature to "acting out" behavior. Using data on automobile traffic circulation and traffic accidents, they find a spike in fatalities three days following an attack. While acknowledging that a three-day lag is a puzzle-why not two or four days-Stecklov \& Goldstein note that response lags of this length have been reported in studies of homicides after boxing matches and in investigations of imitative suicides.

Coping is a theme in the terrorism literatures of both Israel and Northern Ireland, though the concerns of researchers in the two countries are different and there are few crossreferences. In the Israeli materials, there is no discussion of dissociative coping, a cognitive style that might have been adaptive in Northern Ireland but that is recognized as an emotional disorder (American Psychiatric Association 2000, pp. 519-33). Rather, the emphasis in Israel is on coping as a behavioral strategy for confronting mortal risk. Thus, Gidron et al. (1999) in an examination of bus commuters ${ }^{4}$ distinguish between "emotion-focused coping" (e.g., denial of the risk; self-distraction to reduce anxiety) and "problem-focused coping," (e.g., reporting suspicious packages; avoiding high-risk commuter lines). They conclude that while problem-focused coping has clear protective value, it is less efficacious than denial or calming distractions in reducing anxiety.

Bleich et al. (2003) used the same coping style categories with a representative national sample. They find that instrumental modes of coping, which they associate with sound emotional health, are far more common; only a small proportion of the Israeli population appears to use self-distraction or denial to reduce anxiety. Studies of adolescents (e.g., Braun-Lewensohn et al. 2008, Tatar \& Amram 2007) have come to

\footnotetext{
${ }^{4}$ Israelis feel especially exposed when using public transportation. In the two year period 2000-2002, attacks on buses, on trains, and at bus stations resulted in 171 deaths. Gallows humor can be a form of coping: "You know the difference between Russian roulette and Israeli roulette? In Russian roulette, you choose your bullet. Here you just pick a bus" (Bennett 2002, p. 1).

a similar conclusion, namely that the majority utilize problem-solving strategies. Of some interest is the differential coping by Palestinian and Jewish citizens of Israel in light of the source of the terrorist attacks. Hobfoll et al. (2006) examine stress symptoms in the two populations, noting that Palestinians were much more likely than Jews to report PTSD and depressive symptoms. Whereas it is easy for Jewish Israelis to express solidarity in the face of the threat, Palestinians are more affected emotionally as deep issues of identity surface for them. Thus, a Durkheimian explanation of the impact of an external threat on group solidarity makes sense for the Jewish population, but the circumstance of the Palestinian citizens probably requires a cognitive dissonance type of formulation.

The literature on population morale also addresses resiliency, but from a more sociological perspective. Zussman et al. (2007) examine the effects of terrorism on life satisfaction (happiness) during the Palestinian Intifada, concluding that the attacks had practically no impact on the morale of Jewish Israelis, thereby casting doubt on their effectiveness in achieving the terrorist goal of demoralizing an enemy population. Consistent with Hobfoll et al. (2006), they find a negative effect of terrorism on the morale of Palestinian citizens. Zussman \& Romanov (2006) report results that are only partially consistent with Zussman et al. (2007), noting that major attacks (more than 5 deaths) reduce subjective well-being on the day of the event, but that the effect dissipates within a few days. Assessing this literature, Elran (2006) concludes that Israelis remained resilient during the years of the Intifada and that whenever the volume of the attacks decreased, tension lessened and there was a return to routine patterns of behavior.

The theme of social resilience receives its fullest development in an edited volume by Friedland et al. (2005). The chapter by Kirschenbaum (2005) on adaptations to the threat of attack provides considerable detail on coping behavior. Based on a sample of 800 households, representative of the Israeli 
population, Kirschenbaum reports that $12 \%$ of respondents had personally been present at an attack; a further $60 \%$ were acquainted with a victim of terrorist violence-quite high exposure rates for a national population. Regarding modes of coping, Kirshenbaum notes a heavy emphasis on problem-solving adaptations. Behavioral changes as a result of the threat include greater reliance on taxis than buses, sitting near the vehicle's exit when boarding a bus, patronizing retail establishments that have guards, and entertaining more at home, but also a greater reliance on faith and prayer (Kirschenbaum 2005, Table 3). Kirschenbaum's examination of individual adaptations in different behavioral areas brings us to a consideration of the consequent adjustments made by institutions and required of commercial actors in order to remain economically viable in a context of ongoing terrorist activity.

\section{CHRONIC TERRORISM: EFFECTS ON ORGANIZATIONAL ACTORS}

Institutions play a central role in determining the response to terror by residents of a country. Whereas individuals alter their behavior in seeking to cope with the insecurity, organizational actors condition the sorts of adjustments that can be made. At the same time, organizations may find themselves in a dramatically altered environment, requiring them to develop new arrangements to meet the perceived safety needs of the public.

This topic is almost uniquely the province of research on Israel. For reasons already noted, the case of a single massive attack is viewed as so very distant from normality that it has prompted few modifications in the daily routines of individuals. Northern Ireland did experience chronic terrorism; however, accounts of the effects on commercial firms and on other organizations are few, pretty much limited to reports of the duplication of services that arose from the rending of the society along sectarian lines (e.g., O'Farrell 2005). Some attention has been given to the summary costs of the protracted conflict in Northern Ireland, with the finding that there has been heightened emigration, loss of tourist revenue, and high expenditures for security (Jackson et al. 2007). This assessment, however, is based on aggregate data for the region, without an exploration of the details of the adjustments made by individuals and organizations.

A study of taxi drivers in Belfast by Gambetta \& Hamill (2005) is an exception. During the troubles, taxi drivers were the target of hijackings and shootings by paramilitary groups. Taxi firms responded by organizing into separate companies in Protestant and Catholic areas that took fares only to destinations within the respective community; a different type of firm"public hire" taxis - traversed sectarian boundaries. In the case of the former, the problem for taxi drivers was to ascertain that a fare was of the same religious persuasion, but in the latter type of firm the strategy of a taxi driver was to camouflage his own religious identity, especially when the destination was in the other community. Gambetta \& Hamill describe the various approaches adopted by customers and taxi drivers to signal to the other a sense of trustworthiness.

The research in Israel is more comprehensive with respect to organizational adaptations, linking them to behavioral shifts by individuals to reduce their risk. Some 20 years ago Kimmerling (1985) noted that since its founding Israel has had to contend with a perpetual state of conflict with its neighbors. In the process it has developed a flexible social system that permits rapid adjustments during periods of acute military crisis. Kimmerling was writing about the impact of intermittent war and disruptions from having to mobilize large segments of the population, but his argument also pertains to terrorist attacks. Chronic terrorism over many decades has required Israeli institutions to formulate and refine policies for minimizing its impact. These include governmental programs to quickly rebuild an attack site, compensate victims, and memorialize the fallen. Several nongovernmental organizations (NGOs) supplement these tasks with their own activities, sometimes motivated by religious 
imperatives. Commercial establishments have had to develop their own sorts of adaptations, in this case driven by the necessity of responding to changes in patronage by risk-averse customers.

\section{The Government and Nongovernmental Organizations}

To lessen the impact of an attack on the morale of the population, ${ }^{5}$ the Israeli government has instituted a policy of rapid cleanup. If the attack is at a retail establishment, then within hours the street is swept, shattered windows are replaced, and other repairs are undertaken. Complementing these efforts, ZAKA, an ultrareligious $\mathrm{NGO}$, combs the impacted area for human remains and prepares the dead for burial. This activity is taken so very seriously that ZAKA members are continually on call, with transportation ready; often they appear at an attack site as quickly as the ambulances (Stadler et al. 2005). In short, despite the chaos, a semblance of normality is quickly established, and there is a sense that the fatally injured have received respectful treatment.

Victims of attacks are quickly compensated by Bituach Leumi, a quasi-governmental agency similar to the U.S. Social Security Administration. ${ }^{6}$ As a country that frequently has had to put its youth in danger and has striven to present soldiering in narratives of heroism and honor (Bilu \& Witztum 2000, VinitzkySeroussi \& Ben-Ari 2000), Israel provides extensive services to the families of the fallen. A 1970 law extended this consideration to victims of terrorist attacks, defining them, along with soldiers, as casualties in the battle for the

\footnotetext{
${ }^{5}$ A critical contribution to population morale is the high credibility of the government in its efforts to protect the population. These include military strikes into the West Bank and Gaza, intended to disrupt the terrorist infrastructure, as well as a variety of security measures such as ones adopted with regard to airline safety. The comprehensiveness of passenger scrutiny is legendary, as anyone who has come to Israel on El Al Airlines can attest (Tucker 2003).

${ }^{6}$ The comments in this section are based on interviews we conducted with the senior staff of Bituach Leumi.

state's existence. ${ }^{7}$ Additionally, all persons who entered Israel legally and become casualties of a terror attack are entitled to this assistance, including tourists and foreign workers.

Because terrorist attacks are sporadic, few staff members of Bituach Leumi have dedicated responsibilities to this work. But when an attack takes place, there is an immediate shift in the agency's operation. Hotlines are opened; the staff goes to hospitals to see victims; if there are fatalities, they visit with the families during grieving. The staff is available both day and night. Tasks of these sorts are labor intensive. When the needs in an attack area exceed the capability of the local staff, workers are brought in from other offices. Also, the emotional demands of this work are considerable, and counseling is provided, when necessary, to staff workers.

If government agencies and NGOs have taken on the chore of attributing meaning to the loss of life and maintaining solidarity, commercial actors have had to face the task of adapting to the changing behaviors of the public that were prompted by the attacks. Studies of the effects of terrorism on economic behavior can usefully be put into two categories: effects on macroeconomic indicators and the consequences for particular industries. In the first category are examinations of the economic performance of the country; we also include here studies of the impact of the attacks on electoral outcomes because it is a macro variable. The second category covers a variety of industries; most have been adversely affected by the terror, though some, such as protective services, have benefited from a climate of fear and threat. A number of the studies are based on household surveys of consumption, which permit insight into how the socioeconomic characteristics of individuals have influenced their adaptations.

\footnotetext{
${ }^{7}$ The national day of mourning for fallen soldiers of Israel's wars was renamed to include terror victims. The intent is to underscore the view that civilians in Israel are also at the frontline of the battle. The state hopes that by turning terror victims into war heroes they are manufacturing social consent and support for its policies.
} 


\section{Macroeconomic Consequences}

The overall impact of terror on the economy is complex, and there is some dispute as to whether terror has a large or a small effect. Reviewing this literature, Krueger (2007, p. 119) concludes that if terrorism is frequent and sustained, the effect can be considerable. In the case of Israel, a number of studies support this view. Eckstein \& Tsiddon (2004) find a negative impact on GNP, investments, and exports. Undertaking a counterfactual experiment, they conclude that in the period 2000-2003 terrorism was responsible for a reduction in per capita production output of some 10\%. Persitz (2007) reports similar findings, adding that the average Israeli lost some $12 \%$ of real income during this period. In a more general study of macroeconomic effects, Blomberg et al. (2004), using panel data from 177 countries covering the interval 1968-2000, conclude that terrorism consistently had a negative impact on economic growth. Also, it had the effect of redirecting economic activity away from investment and toward government spending.

Haj-Yehia (2006) examined how the temporal pattern in consumption expenditures has been affected by the attacks. He suggests that Israeli households tend to perceive the terror as temporary; this is because the military takes steps to suppress new outbreaks and because the Israeli experience has been one of intense episodes of attacks followed by long periods of relative calm. Extrapolating from a general equilibrium model of temporary income shocks on the timing of purchases, Haj-Yehia argues that the experience of "temporary terror" should have a greater effect on purchases of durable goods than nondurables, initially delaying the former. Over a long period, this would generate a boom-bust cycle in durables expenditures, with the bunching of purchases after an initial delay. Using time series data on attacks during 1980-2002 along with national accounts figures, Haj-Yehia reports strong support for both contentions.

The stock market has been of particular interest to researchers because the data are pub- licly available, collected daily, and appear responsive to mood swings in the population. Eldor \& Melnick (2004) have examined the loss in stock market value due to terrorist attacks. Utilizing a counterfactual strategy, they estimate that the Tel Aviv- 100 index was $30 \%$ lower in 2003 than in 2001, a consequence of the intense terrorist activity in this period. When the attacks were disaggregated by method of execution (suicide, armed assault, bombing, kidnapping), they found that the stock price reduction was largely a result of the suicide attacks; this type of assault appears to generate the greatest fear and anxiety.

An interesting application of the stock market data has been to assess the reaction to assassinations of senior leaders of terrorist organizations. This counterterrorism policy of the Israeli military has been controversial, both for moral reasons and because of questions about its effectiveness. Zussman \& Zussman (2006) undertook an investigation of the immediate effects of the attacks on the morale of Israelis, as measured by stock market moves on the Tel Aviv exchange. They report that the market declined after assassinations of senior political leaders but rose following the targeted killing of military leaders. They interpret the stock moves as suggesting that the first type of action is viewed by the public as counterproductive, likely to lead to further attacks, but that the second is considered an effective counterterrorism strategy.

It is intimated by Zussman \& Zussman (2006) that the magnitude of stock market moves reflects the extent of media coverage of an attack. Melnick \& Eldor (2007) examine this relationship more closely. They find that media coverage is the main channel by which terrorist attacks produce market declines; other characteristics of an attack (e.g., locale, number killed) have no effect once the extent of coverage is controlled. Indeed, the magnitude of the market decline following an attack is a monotonic function of the amount of coverage. These results reinforce the notion that media coverage is a critical route by which terrorism achieves 
its objective of demoralizing the public in a targeted country. However, Melnick \& Eldor note that, with the passage of time, the impact of the media coverage of an attack declines, suggesting a tendency toward routinization of the threat in the consciousness of Israelis.

The influence of terrorism on politics can be profound and is one of the primary goals of the attacks. Terrorists are keen on changing opinions and determining the discourse in a democracy, if not altogether toppling a government. They clearly have the potential to impact public opinion and electoral outcomes. Willer (2004) used Gallup poll data from the United States from 2001-2004 and time series methods to show that government warnings about terror threats led to increased support for President Bush. In Spain, the Madrid train bombings in 2004 are credited with bringing about the victory of the Socialist party in that year's parliamentary elections (Bali 2007).

The effect on election outcomes in Israel is addressed in two recent papers by Berrebi \& Klor $(2006,2008)$. The main finding is that the electorate is sensitive to terrorist fatalities, with attacks shortly before an election generating support for right-leaning parties, whereas periods of calm favor the leftist factions. Since the parties on the right are more intransigent toward territorial compromise, why then do the terrorists choose to attack before an election? Berrebi \& Klor speculate that, because there are several Palestinian terrorist groups with competing agendas, the reasons for a particular attack can be difficult to decipher. For some groups the intent is to sabotage the peace process, while others may want to provoke Israeli retaliation in the belief that this will radicalize the Palestinian population, potentially providing them with new recruits. In short, what may appear counterproductive in terms of the manifest goals of the Palestinian movement can be quite rational at the level of the operative terrorist group.

Thus, the summary effects of the terror on Israeli society are that they have been costly and disruptive. The attacks of the Second Intifada (post-September 2000) are credited with reducing economic output in the country by some $10 \%$ over what it otherwise would have reached; also, electoral decisions have been deeply influenced by the timing of the attacks. Indeed, the moderate political parties have been weakened, and many Israelis now hold the view that terror attacks will continue even if a political settlement is reached with the Palestinian leadership (Bar-Tal \& Teichman 2005). At the same time, economic development in the country has been robust, and, judging from the psychological literature, the morale of the population has not eroded much.

\section{Impact of the Terror on Different Industries}

There are quite interesting dynamics within the economy of an impacted country that highlight the shifting incentives and opportunities arising in a context of chronic terror. These processes can be discerned when specific economic sectors are examined. Thus, retail establishments and public transportation are particularly exposed. They have often been the targets of attack, and customers are quick to adjust their patronage behavior when they sense that they are at risk. Firms in other industries might not be directly exposed but can be harmed by shifting customer behavior in the establishments that they provide with stock. In still other industries, such as defense and security, the companies might well benefit financially from a context of threat and terror.

Tourism is fickle, as destinations can easily be substituted. Tourists often choose among multiple enticing sites and may be deterred from vacationing in a country if there is fear for personal safety. Indeed, several studies have traced declines in tourism to terror attacks [see Aziz (1995) for Egypt; Mansfeld \& Kliot (1996) for Cyprus; Mansfeld (1999) and Morag (2006) for Israel]. Enders \& Sandler (1991) estimate that a typical terror attack in Spain between 1970 and 1988 led to a decline of 140,000 tourists in the following months. In a panel study of the impact of terror in the period 1977 to 2000 , covering all countries with available 
data, Neumayer (2004) concludes that a onestandard deviation increase in terror events in a country lowered tourist arrivals by $8.8 \%$.

An interesting addition to this literature concerns the differential response by foreign and domestic tourists in Israel. Fleischer \& Buccola (2002) examine hotel stays and find the expected decline by foreign tourists, but no reduction by Israelis; indeed, they report a small increase in hotel stays by Israelis during periods of high terror. They attribute this to a supply effect; management reduces prices in an attempt to fill rooms left vacant by the decline in foreign tourism. It appears also to reflect a tendency by local residents to temporarily leave the main cities, which are frequent terrorist targets, for hotels elsewhere in the country.

Tur-Sinai (2006) collected data on commodity purchases from large retailers during the period 2000-2004 and used this material to examine the responses by consumers to terror attacks. He divided purchases into durable and nondurable goods and examined the change in average sales during the three days following an attack with the three days prior to the event. Tur-Sinai finds a larger decline in the purchase of durables, but also a tendency for the impact of terror to weaken over time. He interprets the latter result as suggesting a habituation effect-acceptance of the possibility of an attack as a "normal risk," similar to that of a traffic accident.

A step toward exploring the effects on different industries is provided by Berrebi \& Klor (2005). They sought to assess the relative impact of terrorism on defense- versus nondefense-related companies. Using stock market data on 65 Israeli firms, matched with counterpart companies in the United States to establish a counterfactual, they examined stock movements during the interval January 1998September 2001. Since the Second Intifada uprising began on September 28, 2000, the selected time interval can be viewed as including both pre- and post-treatment periods. Consistent with other studies of effects on the economy, they find a significant negative impact of terrorism-but only for nondefense companies.
For firms in the defense or security industry, the violent outbreaks had a positive effect on stock valuations. They conclude that much of the increase was due to heightened exports of Israeli defense products to other countries-a perverse benefit from having had the opportunity to field test antiterrorist equipment in one's own country.

The security industry has grown rapidly because restaurants, cafes, and other retail establishments have been the target of many attacks, and customers have rapidly adjusted their shopping behavior to reduce risk. Customers not only move to stores in closed shopping malls, ${ }^{8}$ but also show a preference for guarded establishments when patronizing street cafes and restaurants. As a consequence, there has been an expansion of security guard services, from $1.3 \%$ of the labor force in 1995 to $2.0 \%$ in 2003. Many of the new workers have been recruited as they complete military service; thus, the average age of security workers has declined. Also, the new job opportunities have encouraged the weaker socioeconomic segments of Israeli society, such as recent immigrants, to seek employment in the security sector despite the risks inherent in the work (Handels 2004, Shemesh 2007).

According to the director of a large security firm whom we interviewed, the labor demand in the industry can be divided into two categories: one for combat-skilled guards who are employed at high-profile institutions and another for less skilled security workers who are stationed in front of restaurants and small retail establishments. Demand for the highly skilled workers has not grown, as they tend to be permanent employees engaged at work sites that have been guarded for many years. However, there has been a huge increase in the demand for less skilled guards. Retail establishments use

\footnotetext{
${ }^{8}$ Mall security in Israel is organized in concentric circles, with checks of the trunk and passenger compartment of vehicles entering the parking area and the questioning of drivers to determine whether they pose a security threat. Unlike in the United States, ethnic profiling is used. Inside the mall, armed security guards patrol and observe shoppers. Israel has had ten attacks against malls in recent years, but none has penetrated into the interior (Davis et. al. 2006, p. 30).
} 
them as deterrents, hoping that a terrorist will chose another, less protected target. In some cases the guards are not armed or carry fake guns. Indeed, some store owners fear that an armed guard could be a menace to patrons, especially because the danger often comes in the form of a suicide bomber who is attempting to blend in with other customers.

This raises an issue of the dilemma faced by a security guard when he suspects that an approaching person is a suicide bomber. His job assignment is to prevent the person from entering the establishment. But if the suspicious person is challenged, and he is a terrorist, he likely will ignite the bomb, killing the guard as well as himself. Carrying a weapon does not solve the problem unless the guard is prepared to use it whenever an approaching person appears suspicious. Although we did not succeed in getting a clarification of this problem in our interview, the fragility of the task of the guard was made clear in a newspaper article following a 2005 attack at the entrance to a shopping mall in the city of Netanya in which a security worker was killed when he confronted a suicide bomber. Several guards subsequently quit; one remarked: "Only a fool will stay in such a job, or a person who wants to commit suicide" (Ben-Zur 2005).

Studies of the Israeli experience appear now to be focusing on the dynamic response to attacks and how this varies by socioeconomic group and by type of target. For example, if a bus is attacked, what is the impact on ridership and how long before it returns to the prior level? Further, is there a differential response in ridership by social class or other background characteristics? To these questions we add considerations of how individuals reassess their vulnerability after an attack is reported in the media. Thus, what is the response to an attack at one kind of target (e.g., a bus) on the patronage of other sorts of establishments (e.g., restaurants)? Similarly, what is the effect of an attack in one city on the behaviors of residents in a different city? Although studies of these issues are only beginning, there already are results worth noting.
Becker \& Rubinstein (2007) have made the most consequential contribution to our understanding of these matters. Using the Israeli Household Expenditures Surveys for 19992004 and associated biweekly diaries, they constructed a data set containing daily household expenditures for bus transportation, taxis, coffee houses, and restaurants, along with background characteristics of the respondent. These materials have permitted an examination of the dynamic response by the public to different sorts of attacks.

Public buses have been a frequent target of terrorists, and because passengers are crowded in a confined space these assaults have been particularly lethal. From 2000-2005, there were 23 bus attacks, resulting in 205 fatalities (Becker \& Rubinstein 2007, Table 2). ${ }^{9}$ How, then, does bus ridership respond in the days following an attack? Using Poisson regression models, Becker \& Rubinstein report that the number of bus tickets sold in the week following a bus attack declined by $5.7 \%$. However, much of the fall off was temporary; two weeks later some half of the initial loss had been recovered.

Becker \& Rubinstein (2007) also examined whether riders take into account the level of risk of the bus route. Most of the attacks have taken place in the metropolitan regions of the country. Dividing the sample into households residing in a major city and those living elsewhere, they note that the fall off in ridership after a bus attack is much greater for city dwellers. This finding is reinforced by an examination of expenditures for taxi rides following a bus attack. Not surprisingly, the increased use of taxi services takes place entirely in the metropolitan areas. Thus, there is clear evidence of a

\footnotetext{
${ }^{9}$ Because attacks on buses have come to symbolize the vulnerability of the civilian population, the Israeli government set up policing units called "Magen units" in 2001, which included specially trained guards and dogs to systematically inspect popular bus lines. In interviews, an official at Dan Bus Lines in Tel Aviv described a myriad of strategies used by the company to protect passengers. These include spot checks by police units as well as technologies to sniff explosives at the entry to buses. Yet, the official's view was that these strategies are more effective in providing a sense of security to riders than in stopping a determined terrorist.
} 
substitution effect in mode of transportation in the locations where commuters feel most threatened.

Along with buses, coffee shops and restaurants were frequent targets of terrorists, and Becker \& Rubinstein (2007) assessed the effects of an attack on the patronage of these establishments. In this case, the exposure variable is "attack not on a bus," and they find that this event is associated with a reduction of $15 \%$ in the number of visits to cafes and restaurants. Dividing the sample into single and married respondents, they note that the patronage decline is entirely due to behavioral shifts among the married. Single persons, they speculate, are dependent on these public places for meeting and dating activity, making them more inclined to assume the risk of a possible attack.

The theme of differential response by distance from the attack site is picked up by Stecklov \& Spilerman (2008). They used a data set on daily sales at three cafes in a chain of coffee houses. While all the stores are located in the Jerusalem region, they differ in vulnerability to an attack. Two are exposed to street traffic, while the third is in a gated shopping mall. Not surprisingly, the response to a terror incident is a decline in sales in the exposed shops, but little change in the protected cafe. In the former, the sales decline is brief, dissipating after 3-4 days. When the attacks are categorized by distance from Jerusalem ("within the city" versus "elsewhere"), the incidents in Jerusalem showed a much stronger impact on the exposed shops. A summary calculation finds a sales reduction from an attack in Jerusalem, relative to an attack elsewhere, of $7.6 \%$ in one of the exposed coffee shops, $4.5 \%$ in the second. Again, sales in the protected shop are not significantly affected by an attack, whether in the city or elsewhere.

Apparently, then, individuals code their vulnerability in terms of physical proximity to the site of a recent attack. What about the target of the attack? Do people associate vulnerability in a particular behavioral area with the choice of target in a recent attack? Stecklov \& Spilerman (2008) examined this issue by comparing the change in coffee shop sales depending on whether the attack was at a restaurant/coffee shop or on a bus. The results are dramatic: sales at the two exposed coffee houses averaged a $2.5 \%$ reduction in the days immediately following a bus attack, but a $23 \%$ reduction subsequent to an assault at an eating establishment. Clearly, whether rational or not, individuals assess risk in terms of the similarity of a contemplated behavior to the target of a recent attack.

To summarize, the Israeli material conveys the complexity of adaptations in different sectors of the economy. At one extreme are bus lines, restaurants, and cafes, which have borne the brunt of the attacks. At the other extreme are the security guard firms that have thrived on the terror threat and now even market their expertise to other countries. Yet, even for them there is concern about the economics of a boom-and-bust business. The demand for guard services is highly volatile, as many retail establishments are quick to shed the cost of guard services as soon as there is a lull in attacks. Indeed, the rapid recovery of patronage at cafes and restaurants makes clear that the problem for retail firms is largely short term, except when there is a prolonged series of attacks.

\section{CONCLUSIONS}

Terror's primary aim is to achieve a political or emotional victory rather than an outright military defeat of the enemy country. This is accomplished by the targeting of civilians and national symbols of the society. Thus, while the casualty count is generally lower than in war, and the structure and institutions of the society are left basically intact, terrorism can generate widespread fear and anxiety, prompting changes in behavior and in organizational arrangements. However, because the society is generally left intact, we can study the social consequences of terror to identify the pathways by which individuals and institutions have adapted. What, then, have we learned about the impact of terror attacks on a social system?

First, the temporal pattern of the attacks matters greatly. Chronic terrorism leaves a much more pervasive footprint on a society than 
a single strike, however massive. In the case of a one-time attack, the abnormality of the situation tends to be emphasized. In terms of $\operatorname{cog}$ nitive processing, it is so far outside the range of normal experience that, although the attack may provoke acute stress, it does not alter one's concept of normality or require a modification in coping style. The research questions that are posed center upon the extent of perturbation from one's emotional stasis and the time path in the return to equilibrium. Not surprisingly, the more sociological investigations concerning the impact of an attack on organizational actors are also cast in the imagery of exogenous shocks and stages in the return to normal functioning. The disasters model, which conforms well with this imagery, has therefore come to be the focal paradigm in studies of the impact of solitary attacks.

Chronic terrorism, by contrast, provokes adjustments that are deep and long lasting. Because the population is constantly under risk of attack, often for many years, a different sense of normality has to be internalized. While the attacks continue, there can be little expectation of a return to the status quo ante. At the psychological level, this raises issues of what is an appropriate coping style in this kind of menacing environment, as well as questions of population morale; the latter is a particular concern of a government seeking to frustrate the intent of the terrorists. At the macro level, terrorism has a negative effect on aggregate economic output, though there is considerable heterogeneity in how different industrial sectors tend to fare. In short, the impact of terrorism is far from uniform.

Second, the social context matters. This is especially the case with respect to chronic terrorism because there is more time for the adjustments to unfold against a background of specific institutional arrangements. In a sectarian-riven country, the terrorist attacks appear to initiate a dynamic that reinforces existing cleavages and divisions, with the effect of further polarizing the society-at least, this is the story with respect to Northern Ireland. However, in a relatively cohesive society like
Israel, the fact that the threat comes from actors external to the state serves to heighten solidarity as the residents come to see themselves as confronting a common threat. In Israel, the approach taken to enhancing security is many layered. It begins with military actions against the terrorist groups and moves to interdiction and apprehension strategies by the police and then to the protective steps taken by commercial firms for their own safety. But successful strikes do occur, and Israelis have come to accept some level of terrorism as a fact of life, much as they do road accidents. Actions by the government to minimize the impact on population morale when an attack is successful then come into play.

From a sociological point of view, chronic terrorism in a cohesive society is probably the most interesting case because it produces a rich array of behavioral changes and compensatory adjustments by institutions and commercial firms. On the surface, the behavioral modifications would seem to be rational; thus, there is less use of public transportation and fewer visits to restaurants because both have been frequent targets of terrorists. However, this rationality tends to have a short temporal horizon, and after an attack there is a rapid return to prior behavioral routines. Moreover, individuals appear to associate risk with similarity of a locale to the site of an immediately prior attack, though there is no reason to think that a strike on a bus makes another bus attack more probable than, say, the bombing of a restaurant.

Commercial establishments must be responsive to the concerns of customers, and the Israeli studies make clear the range of adjustments that have been taken to convey at least a sense of safety. One of the more interesting organizational developments concerns the emergence of a new type of private security firm that specializes in the provision of guards to retail establishments. Private security is hardly novel, but these firms have traditionally operated in an environment in which demand is stable, or at least can be predicted. In Israel, however, the demand is intense immediately following an attack but then declines rapidly, requiring a large 
pool of potential guards willing to work for brief periods. This personnel problem is managed by recruiting college students and the recently demobilized, as well as pensioners and the unemployed. Given that army service is nearly universal in Israel, there are many in each category with small arms training who are available for short-term employment.

The theoretical models that apply to social system adjustments in the case of chronic terrorism are less developed than in the case of a single strike. There is no coherent counterpart to the disasters model that might provide an account of the unfolding adaptations that take place in a country confronting frequent attacks, although the Israeli experience provides some insight into how terrorist shocks cascade through the system and are dealt with and absorbed. While the adjustments clearly depend on the social organization and institutional arrangements in a country, the Israeli case provides a starting point for comprehending the consequences of a prolonged encounter with terrorism.

The exposure to terrorism in the United States is limited, and public awareness of the terrorist menace has been molded by a very few attacks on prominent public buildings. But in many respects the greater threat to morale and to social stability might come from frequent small-scale assaults on diverse mundane targets-a bombing on a bus or subway, in a restaurant or department store, or on a crowded street. Such attacks would be deeply intrusive in our daily lives and in our association of safety with routine activities. They would make clear our constant vulnerability to mortal attack and raise concerns, each morning, about loved ones when they depart for work or school. Yet, there are countries that have had to confront this sort of menace for many years, and we would do well to learn from their experience.

One may also wonder about the new bonds that are being forged by common encounters with terrorism. This possibility was expressed in an interview with Indian businessmen following the November 2008 terror attacks in Mumbai, in which they remarked on their new-found feelings of empathy with Israelis (Freedman 2008, p. A21). More generally, Beck (2002, p. 43) has suggested that because societies are facing common threats-from terror as well as from financial and ecological risks-this will likely stimulate the formation of new and novel international arrangements. Clearly, we stand at the beginnings of a portentous era in globalization and have a great need to construct institutions that can handle the profound challenges.

\section{DISCLOSURE STATEMENT}

The authors are not aware of any biases that might be perceived as affecting the objectivity of this review.

\section{ACKNOWLEDGMENTS}

This study was supported by Ford grant \#1040-1239 to Seymour Spilerman and by a grant to Guy Stecklov from the Silbert Center for the Study of Israel. We thank Catherine Silver for her insights into the psychiatric themes discussed in the paper and Yinon Cohen and Florencia Torche for their helpful comments on an earlier draft. We also thank Amanda Karl for her insightful observations about terrorism in Northern Ireland.

\section{LITERATURE CITED}

Allen L. 2008. Getting by the occupation: how violence became normal during the Second Palestinian Intifada. Cult. Antbropol. 23:453-87

Am. Psychiatr. Assoc. 2000. Diagnostic and Statistical Manual of Mental Disorders_DSM-IV-TR. Washington, DC: Am. Psychiatr. Assoc. 
Atran S. 2003. Genesis of suicide terrorism. Science 299:1534-39

Aziz H. 1995. Understanding terrorist attacks on tourists in Egypt. Tour: Manag. 16(2):91-95

Baker GW, Chapman DW, eds. 1962. Man and Society in Disaster. New York: Basic Books

Bali VA. 2007. Terror and elections: lessons from Spain. Electoral Stud. 26:669-87

Bar-Tal D, Teichman Y. 2005. Stereotypes and Prejudice in Conflict: Representations of Arabs in Israeli Society. Cambridge, UK: Cambridge Univ. Press

Barton AH. 1962. The emergency social system. See Baker \& Chapman 1962, pp. 222-67

Barton AH. 1963. Social Organization Under Stress: A Sociological Review of Disaster Studies. Washington, DC: Natl. Acad. Sci.

Barton AH. 1969. Communities in Disaster: A Sociological Analysis of Collective Stress Situations. Garden City, NY: Doubleday

Baum A, Dougall AL. 2002. Terrorism and behavioral medicine. Curr. Opin. Psychiatry 15(6):617-21

Beck U. 2002. The terrorist threat: world risk society revisited. Theory Cult. Soc. 19:39-55

Becker GS, Rubinstein Y. 2007. Fear and the response to terrorism: an economic analysis. Work. Pap., Dep. Econ., Univ. Chicago

Bennett J. 2002. Dread and dreams travel by bus in Israel. New York Times, Oct. 27, p. A1

Ben-Zur R. 2005. Natanya mall security guards quit. Ynet News Dec. 13. http://www.ynetnews.com

Berrebi C, Klor EF. 2005. The impact of terrorism across different industries: an empirical study. Work. Pap., Rand Corp., Santa Monica, CA

Berrebi C, Klor EF. 2006. On terrorism and electoral outcomes-theory and evidence from the IsraeliPalestinian conflict. 7. Confl. Resolut. 50:899-925

Berrebi C, Klor EF. 2008. Are voters sensitive to terrorism? Direct evidence from the Israeli electorate. Am. Polit. Sci. Rev. 102:279-301

Bilu Y, Witztum E. 2000. War-related loss and suffering in Israeli society: an historical perspective. Isr. Stud. $5: 1-31$

Bleich A, Gelkopf M, Solomon Z. 2003. Exposure to terrorism, stress-related mental health systems, and coping behaviors among a nationally representative sample in Israel. $7 A M A$ 290(5):612-20

Blomberg SB, Hess GD, Orphanides A. 2004. The macroeconomic consequences of terrorism. F. Monet. Econ. 51:1007-32

Braun-Lewensohn O, Celestin-Westreich S, Celestin L, Verleye G, Verte D, et al. 2008. Coping styles as moderating the relationships between terrorist attacks and well-being outcomes. 7 . Adolesc. In press

Bruck T, Wickstrom BA. 2004. The economic consequences of terror. Eur. F. Polit. Econ. 20(2):293-300

Campbell J, Healey A. 1999. 'Whatever you say, say something': the education, training and practice of mental health social workers in Northern Ireland. Soc. Work Educ. 18(4):389-400

Chernick H. 2005. Resilient City: The Economic Impact of 9/11. New York: Russell Sage Found.

Cohen Y. 1988. War and social integration: the effects of the Israeli-Arab conflict on Jewish emigration from Israel. Am. Sociol. Rev. 53:908-18

Curran PS. 1988. Psychiatric aspects of terrorist violence: Northern Ireland 1969-1987. Br. F. Psychiatry $153: 470-75$

Curran PS, Miller PW. 2001. Psychiatric implications of chronic civilian strife or war: Northern Ireland. Adv. Psychiatr. Treat. 7:73-80

Davis RC, Ortiz C, Rowe R, Broz J, Rigakos G, Collins P. 2006. An assessment of the preparedness of large retail malls to prevent and respond to terrorist attack. Final rep., Natl. Inst. Justice, Washington, DC

Dorahy MJ, Mills H, Taggart C, O’Kane M, Mulholland C. 2006. Do dissociative disorders exist in Northern Ireland? Eur. 7. Psychiatry 20(3):172-82

Dorahy MJ, Paterson MC. 2005. Trauma and disassociation in Northern Ireland. F. Trauma Pract. 4(3/4):22143

Eckstein Z, Tsiddon D. 2004. Macroeconomic consequences of terror: theory and the case of Israel. F. Monet. Econ. 51:971-1002

Eldor R, Melnick R. 2004. Financial markets and terrorism. Eur. 7. Polit. Econ. 20:367-86

Elran M. 2006. Israel's national resilience: the influence of the Second Intifada on Israeli society. Work. Pap. No. 81, Jaffee Cent., Tel Aviv Univ., Tel Aviv, Israel (In Hebrew) 
Enders W, Sandler T. 1991. Causality between transnational terrorism and tourism-the case of Spain. Terrorism 14:49-58

Fleischer E, Buccola S. 2002. War, terror, and the tourism market in Israel. Appl. Econ. 34:1335-43

Form WH, Nosnow S. 1958. Community in Disaster. New York: Harper

Freedman SG. 2008. Between Israel and India, a link based on culture and, now, terrorism. New York Times, Nov. 29, p. A21

Frey BS, Luechinger S, Stutzer A. 2007. Calculating tragedy: assessing the costs of terrorism. F. Econ. Surv. 21(1) $1-24$

Friedland N, Arian A, Kirschenbaum A, Fleisher N. 2005. The Concept of Social Resilience. Haifa, Isr.: Samuel Neaman Inst.

Fullerton CS, Ursano RL, Norwood AE, Holloway HH. 2003. Trauma, terrorism, and disaster. In Terrorism and Disaster, ed. RL Ursano, CS Fullerton, AE Norwood, pp. 1-22. Cambridge, UK: Cambridge Univ. Press

Galea S, Ahern J, Resnick, H. Kilpatrick D, Bucuvalas M, et al. 2002. Psychological sequelae of the September 11 terrorist attacks in New York City. N. Engl. 7. Med. 346:982-87

Gambetta D. 2005. Suicide missions: motivations and beliefs. In Making Sense of Suicide Missions, ed. D Gambetta, pp. 233-58. Oxford: Oxford Univ. Press

Gambetta D, Hamill H. 2005. Streetwise: How Taxi Drivers Establish Their Customers' Trustworthiness. New York: Russell Sage Found.

Gidron Y, Gal R, Zahavi S. 1999. Bus commuters' coping strategies and anxiety from terrorism: an example of the Israeli experience. 7. Trauma Stress 12(1):185-92

Gidron Y, Kaplan Y, Velt A, Shalem R. 2004. Prevalence and moderators of terror-related post-traumatic stress disorder symptoms in Israeli citizens. Isr. Med. Assoc. 7. 6(7):387-91

Grosskopf KR. 2006. Evaluating the societal response to antiterrorism measures. F. Homeland Secur. Emerg. Manag. 3(2):1-9

Haddad S. 2004. A comparative study of Lebanese and Palestinian perceptions of suicide bombings: the role of militant Islam and socio-economic status. Int. F. Comp. Sociol. 45:337-63

Haj-Yehia S. 2006. Terrorizing consumers and investors. Work. Pap., Analysis Group, Boston, MA

Handels S. 2004. Security Guards in Israel: 1995-2003. Ministry of Industry. Jerusalem: Gov. Isr. (In Hebrew)

Hill R, Hanson DA. 1962. Family in disaster. See Baker \& Chapman 1962, pp. 185-221

Hobfoll SE, Canetti-Nisim D, Johnson RJ. 2006. Exposure to terrorism, stress-related mental health symptoms, and defensive coping among Jews and Arabs in Israel. F. Consult. Clin. Psychol. 74(2):207-18

Hoffman B. 2006. Inside Terrorism. New York: Columbia Univ. Press

Holman EA, Silver RC, Poulin M, Andersen J, Gil-Rivas V, McIntosh DN. 2008. Terrorism, acute stress, and cardiovascular health. Arch. Gen. Psychiatry 65(1):73-80

Howitt AM, Pangi RL. 2003. Countering Terrorism. Cambridge, MA: MIT Press

International Institute for Counter Terrorism. 2005. Interdisciplinary Center, Herzilya, Israel. http://www. ict.org.il

Jackson BA, Dixon L, Greenfield VA. 2007. Economically Targeted Terrorism. Santa Monica: Cent. Terror. Risk Manag. Policy, Rand Corp.

Jackson OA. 2008. The impact of the 9/11 terrorist attacks on the US economy. 7. 9/11 Stud. 20:1-27 http://www.journalof911studies.com/volume/2008/OliviaJackson911andUS-Economy.pdf

Joas H. 2003. War and Modernity. London: Polity

Jones E, Woolven R, Durodie B, Wessely S. 2006. Public panic and morale: Second World War civilian responses re-examined in the light of the current anti-terrorist campaign. F. Risk Res. 9(1):57-73

Joseph S, Cairns E, McCollam P. 1993. Political violence, coping and depressive symptomology in Northern Irish children. Personal. Individ. Differ: 15:471-73

Killian LM. 1952. The significance of multiple group membership in disaster study. Am. F. Sociol. 57(4):309-14

Kimmerling B. 1985. Interrupted System: Israeli Civilians in War and Routine Times. New Brunswick/London: Transaction Books

Kirschenbaum A. 2005. Adapting behaviors of Israeli civilians to Palestinian terror. In The Concept of Social Resilience, ed. N Friedland, A Arian, A Kirschenbaum, N Fleisher, pp. 36-81. Haifa, Isr.: Samuel Neaman Inst. 
Kirschenbaum A. 2006. Terror, adaptation and preparedness: trilogy for survival. F. Homeland Secur: Emerg. Manag. 3(1):1-33

Krueger AB. 2007. What Makes a Terrorist: Economics and the Roots of Terrorism. Princeton, NJ: Princeton Univ. Press

Krueger AB, Maleckova J. 2003. Education, poverty and terrorism: Is there a causal connection? 7. Econ. Perspect. 17(4):119-44

Lenain P, Bonturi M, Koen V. 2002. The economic consequences of terrorism. OECD Econ. Dep. Work. Pap. No. 334, OECD, Paris

Lopez-Rousseau A. 2005. Avoiding the death risk of avoiding a dread risk. Psychol. Sci. 16(6):426-28

Loughrey GC, Bell P, Kee M, Roddy RJ, Curran PS. 1988. Post-traumatic stress disorder and civil violence in Northern Ireland. Br. 7. Psychiatry 153:554-60

Mansfeld Y. 1999. Cycles of war, terror, and peace: determinants and management of crisis and recovery of the Israeli tourism industry. 7. Travel Res. 38:30-36

Mansfeld Y, Kliot N. 1996. The tourism industry in the partitioned island of Cyprus. In Tourism, Crime and International Security Issues, ed. A Pizam, Y Mansfeld, pp. 187-202. Chichester, UK: Wiley

McDonald G. 2007. Mental health consequences of long term conflict. Br. F. Med. 334:1121-22

Melnick R, Eldor R. 2007. Small investment and large returns: terrorism, media and the economy. Work. Pap., Interdiscip. Cent., Herzelia, Israel

Middleton W. 2004. Dissociative disorders: a personal work in progress. Australas. Psychiatry 12(3):245-52

Morag N. 2006. The economics and social effects of intensive terrorism: Israel 2000-2004. Middle East Rev. Int. Aff. 10:120-41

Muldoon OT, Trew K, Kilpatrick R. 2000. The legacy of the troubles on the young people's psychological and social development and their school life. Youth Soc. 32(1):6-28

Murphy H, Lloyd K. 2007. Civil conflict in Northern Ireland and the prevalence of psychiatric disturbance across the United Kingdom: a population study using the British Household Panel Survey and the Northern Ireland Household Panel Survey. Int. 7. Soc. Psychiatry 53(5):397-407

Murray M, Clifford S. 1988. Anxiety and aspects of health behavior among adolescents in Northern Ireland. Adolescence 23(91):661-66

National Research Council. 2002. Terrorism: Perspectives from the Behavioral and Social Sciences, ed. NJ Smelser, F Mitchell. Washington, DC: Natl. Acad. Sci.

Neumayer E. 2004. The impact of political violence on tourism-dynamic cross-national estimation. f. Confl. Resolut. 48:259-81

O'Farrell J. 2005. Apartheid. New Statesman, Nov. 28. http://www.newstatesman.com/200511280006

Pais JF, Elliot JR. 2008. Places as recovery machines: vulnerability and neighborhood change after major hurricanes. Soc. Forces 86(4):1415-53

Persitz D. 2007. The economic effects of terrorism: counterfactual analysis of the case of Israel. Work. Pap., Dep. Econ., Tel Aviv Univ., Tel Aviv, Israel

Quarantelli EL, Dynes RR. 1977. Response to social crisis and disaster. Annu. Rev. Sociol. 3:23-49

Ricolfi L. 2005. Palestinians, 1981-2003. In Making Sense of Suicide Missions, ed. D Gambetta, chapter 3, p. 81. Oxford: Oxford Univ. Press

Rosenfeld M. 2004. Confronting the Occupation: Work, Education and Political Activism of Palestinian Families in a Refugee Camp. Stanford, CA: Stanford Univ. Press

Rubin GJ, Brewin CR, Greenberg N, Simpson J, Wessely S. 2005. Psychological and behavioural reactions to the bombings in London on 7 July 2005: cross sectional survey of a representative sample of Londoners. Br. Med. F. 331:606-11

Sagerman M. 2004. Understanding Terror Networks. Philadelphia: Univ. Pa. Press

Salib E. 2003. Effect of 11 September 2001 on suicide and homicide in England and Wales. Br. F. Psychiatry $183: 207-12$

Schlenger WE, Caddell JM, Ebert L, Jordan BK, Rourke KM, et al. 2002. Psychological reactions to terrorist attacks-Findings from the national study of Americans' reactions to September 11. FAMA 288(5):581-88

Schuster MA, Stein BD, Jaycox LH, Collins RL, Marshall GN, et al. 2001. A national survey of stress reactions after the September 11, 2001 terrorist attacks. N. Engl. F. Med. 345(20):1507-12 
Shalev AY, Tuval R, Frenkiel-Fishman S, Hadar H, Eth S. 2006. Psychological responses to continuous terror: a study of two communities in Israel. Am. F. Psychiatry 163(4):667-73

Shemesh A. 2007. The influence of terror attacks on the security guard labor market. Work. Pap., Dep. Sociol. Anthropol., Hebrew Univ., Jerusalem. (In Hebrew)

Shughart WF. 2006. An analytical history of terrorism, 1945-2000. Public Choice 128(1-2):7-39

Smelser NJ. 2007. The Faces of Terrorism: Social and Psychological Dimensions. Princeton, NJ: Princeton Univ. Press

Stadler N, Ben-Ari E, Mesterman E. 2005. Terror, aid and organization, the Haredi Disaster Victim Identification Teams (ZAKA) in Israel. Anthropol. Q. 78:619-51

Stecklov G, Goldstein JR. 2004. Terror attacks influence driving behavior in Israel. Proc. Natl. Acad. Sci. USA 101(40):14551-56

Stecklov G, Spilerman S. 2008. The aroma of terror. Work. Pap., Dep. Sociol. Anthropol., Hebrew Univ., Jerusalem

Tatar M, Amram S. 2007. Israeli adolescents' coping strategies in relation to terrorist attacks. Br. F. Guid. Couns. 35(2):163-73

Tierney K. 2007. From the margins to the mainstream? Disaster research at the crossroads. Annu. Rev. Sociol. 33:503-25

Tilly C. 2004. Terror, terrorism, terrorists. Sociol. Theory 22(1):5-13

Tucker JB. 2003. Strategies for countering terrorism: lessons from the Israeli experience. 7. Homel. Secur. March. http://www.homelandsecurity.org/journal/Articles/tucker-israel.html

Turk AT. 2004. Sociology of terrorism. Annu. Rev. Sociol. 30:271-86

Tur-Sinai A. 2006. Adaptation, consumer behavior and terror: an empirical investigation. Work. Pap., Dep. Econ., Tel Aviv Univ., Tel Aviv, Israel. (In Hebrew)

Valverde CV. 2005. Stress reactions of the general population after the terrorist attacks of S11, 2001 (USA) and M11, 2004 (Madrid, Spain): myths and realities. Annu. Clin. Health Psychol. 1:9-25

Vazquez C, Perez-Sales P, Matt G. 2006. Post-traumatic stress reactions following the March 11, 2004 terrorist attacks in a Madrid community sample. Span. F. Psychol. 9(1):61-74

Victoroff J. 2005. The mind of the terrorist-a review and critique of psychological approaches. 7 . Confl. Resolut. 49(1):3-42

Vinitzky-Seroussi V, Ben-Ari E. 2000. "A knock on the door”: managing death in the Israeli Defense Forces. Sociol. Q. 41:391-411

Vlahov D, Galea S, Resnick H, Ahern J, Boscarino JA, et al. 2002. Increased use of cigarettes, alcohol, and marijuana among Manhattan, New York, residents after the September 11th terrorist attacks. Am. F. Epidemiol. 155(11):988-96

Willer R. 2004. The effects of government-issued terror warnings on presidential approval ratings. Curr. Res. Soc. Psychol. 10:1-12

Zussman N, Romanov D. 2006. Terror and its effects on Israelis: evidence of psychic costs of the Intifada. Econ. Q. Israeli Econ. Assoc. 53(2):272-89 (In Hebrew)

Zussman A, Zussman N. 2006. Assassinations: evaluating the effectiveness of an Israeli counterterrorism policy using stock market data. F. Econ. Perspect. 20:193-206

Zussman A, Zussman N, Romanov D. 2007. Does terrorism demoralize? Evidence from Israel. Work. Pap., Dep. Econ., Hebrew Univ., Jerusalem, Israel 